\title{
Recombinant adenovirus expressing vesicular stomatitis virus $G$ proteins induce both humoral and cell-mediated immune responses in mice and goats
}

Xiaojuan Xue ${ }^{1 \dagger}$, Zhaorong Yu ${ }^{2 \dagger}$, Hongyan Jin ${ }^{1,3}$, Lin Liang ${ }^{1}$, Jiayang $\mathrm{Li}^{1}$, Xiaolu Li ${ }^{1}$, Yong Wang ${ }^{1,2}$, Shangjin Cui ${ }^{1}$ and Gang $\mathrm{Li}^{1 *}$

\begin{abstract}
Background: Vesicular stomatitis (VS) is an acute, highly contagious and economically important zoonotic disease caused by the vesicular stomatitis virus (VSV). There is a need for effective and safe stable recombinant vaccine for the control of the disease. The human type 5 replication-defective adenovirus expression vector is a good way to construct recombinant vaccines.

Results: Three recombinant adenoviruses ( $\mathrm{rAd}$ ) were successfully constructed that expressed the VSV Indiana serotype glycoprotein (VSV-IN-G), VSV New Jersey serotype glycoprotein (VSV-NJ-G), and the G fusion protein (both serotypes of G [VSV-IN-G-NJ-G]) with potentiality to induce protective immunity. G proteins were successfully expressed with good immunogenicity. The rAds could induce the production of VSV antibodies in mice, and VSV neutralizing antibodies in goats, respectively. The neutralizing antibody titers could reach 1:32 in mice and 1:64 in goats. The rAds induced strong lymphocyte proliferation in mice and goats, which was significantly higher compared to the negative control groups.

Conclusions: The three rAds constructed in the study expressed VSV-G proteins and induced both humoral and cellular immune responses in mice and goats. These results lay the foundation for further studies on the use of rAds in vaccines expressing VSV-G.
\end{abstract}

Keywords: Vesicular stomatitis virus, Recombinant adenovirus, Immune responses, Mice, Goats

\section{Background}

Vesicular stomatitis (VS) is a highly contagious and economically important disease of cattle, horses, pigs, and other mammals having zoonotic significance $[1,2]$. The etiology of the disease is vesicular stomatitis virus (VSV),

\footnotetext{
*Correspondence: ligang03@caas.cn

${ }^{+}$Xiaojuan Xue and Zhaorong Yu contributed equally to this work.

${ }^{1}$ Beijing Scientific Observation and Experiment Station for Veterinary Drugs and Diagnostic Technology, Ministry of Agriculture and Rural Affairs, China /Institute of Animal Sciences, Chinese Academy of Agricultural Sciences, Beijing 100193, China

Full list of author information is available at the end of the article
}

a RNA virus of the family Rhabdoviridae [3]. The characteristics features of the disease include vesicular lesions in the mouth (lips, gums, tongue), nostrils, coronary band, and teats [4]. Although, no longer listed by the World Organization for Animal Health (OIE), VS is an important disease due to its considerable economic impact on equine events and the fact that it is clinically indistinguishable from foot-and-mouth disease (FMD) $[3,5,6]$. VSV has two main serotypes i.e., Indiana (VSVIN) and New Jersey (VSV-NJ) that are morphologically and pathologically similar, but generate distinct

(c) The Author(s). 2021 Open Access This article is licensed under a Creative Commons Attribution 4.0 International License, which permits use, sharing, adaptation, distribution and reproduction in any medium or format, as long as you give appropriate credit to the original author(s) and the source, provide a link to the Creative Commons licence, and indicate if changes were made. The images or other third party material in this article are included in the article's Creative Commons licence, unless indicated otherwise in a credit line to the material. If material is not included in the article's Creative Commons licence and your intended use is not permitted by statutory regulation or exceeds the permitted use, you will need to obtain permission directly from the copyright holder. To view a copy of this licence, visit http://creativecommons.org/licenses/by/4.0/ The Creative Commons Public Domain Dedication waiver (http://creativecommons.org/publicdomain/zero/1.0/) applies to the data made available in this article, unless otherwise stated in a credit line to the data. 
neutralizing antibodies in infected animals. These virus can be identified by neutralization and complement fixation tests $[7,8]$. Although these two serotypes are morphologically and pathologically similar, in infected animals they generate distinct neutralizing antibodies [9]. The cross-protection between the two serotypes is poor; thus, different vaccines are required for each serotype [10, 11]. From 2004 to 2006, 751 VS outbreaks caused by VSV-NJ were reported in the US [12]. These VS outbreaks also spread from the US to Mexico from 2005 to 2011; however, no new variant strain was produced [13]. As VS can be prevented and controlled by vaccination, some advancements have been made with regard to developing vaccines against VSV. However, further efforts are still needed in developing new vaccines $[10,11,14]$.

The recombinant adenovirus (rAd) vector has been widely used to achieve transient inducible expression [15]. The adenovirus vector can either be replicationdefective or replicative [16]. In the replicationdefective adenovirus vector, all structural genes are removed, and only the vital genes for cis-acting elements and the packaging signal sequence are retained; therefore, its cytotoxicity is significantly reduced. Foreign sequences of up to $37 \mathrm{~Kb}$ can be inserted into this vector. In addition, the cytomegalovirus (CMV) promoter is also inserted into this vector to enable the efficient expression of foreign genes. This expression system is currently the main vector used for rAd vector vaccine research [17].
The vesicular stomatitis virus glycoprotein (VSV-G) contains glycosylation sites and the antigenic determinant [18]. The VSV-G present as protrusions on the virus envelope is strain-specific and capable to stimulate the production of neutralizing antibodies. VSV-G is the preferred antigen for VSV vaccine research [19]. Effective vaccines currently available against VSV are mostly live attenuated. Since attenuated virus has the risks of virulence reversion, a stable vaccine is therefore in need. In this study we assessed the potential of the VSV-G gene as a vaccine candidate by using a replication-defective human adenovirus type 5 expression vector expressing the VSV-IN glycoprotein (VSV-IN-G), VSV-NJ glycoprotein (VSV-NJ-G), and the G fusion protein (both serotypes of G [VSV-IN-G-NJ-G]). Furthermore, we evaluated the immunogenicity of these rAd vectors expressing VSV-G in mice and goats.

\section{Results}

Generation and identification of recombinant adenovirus

The three rAds named rAd-IN, rAd-NJ, rAd-IN-NJ were replicated in AAV-293 cells. After a 10-day incubation period, the cytopathic effect (CPE) was observed in the infected cells (Fig. 1). The three rAds were serially propagated to four generation and the rAds were collected to extract the viral DNA. The VSV-IN-G gene (1536 bp), VSV-NJ-G gene (1554 bp) and the VSV-IN-G-NJ-G gene (3100 bp) were amplified by PCR using specific primers (Fig. 2).
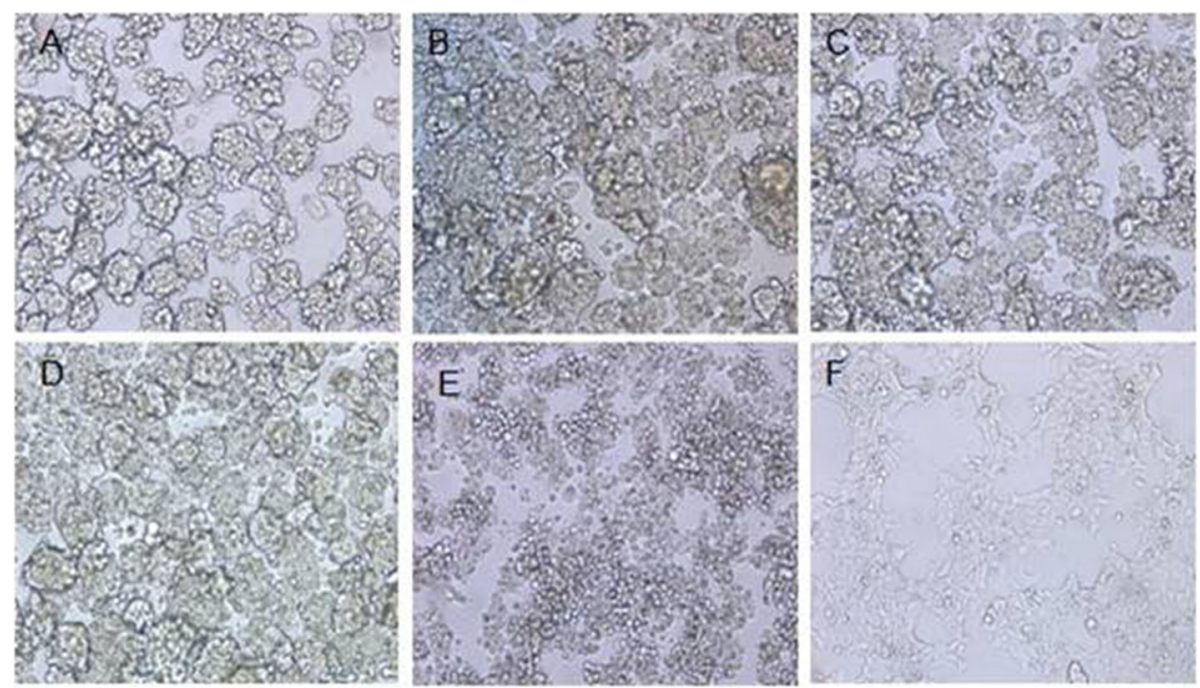

Fig. 1 CPE of AAV-293 cells infected with the recombinant adenoviruses. A: CPE of AAV-293 cells infected with rAd-IN; B: CPE of AAV-293 cells infected with rAd-NJ; C: CPE of AAV-293 cells infected with rAd-IN-NJ; D: CPE of AAV-293 cells infected with wtAd; E: CPE of AAV-293 cells infected with VSV-IN; F: Uninfected AAV-293 cells. CPE, cytopathic effect; rAd-IN, recombinant adenovirus-Indiana, rAd-NJ, recombinant adenovirus-New Jersey; rAd-IN-NJ, recombinant adenovirus-Indiana-New Jersey; wtAd, wild-type adenovirus; VSV-IN, vesicular stomatitis virus-Indiana 


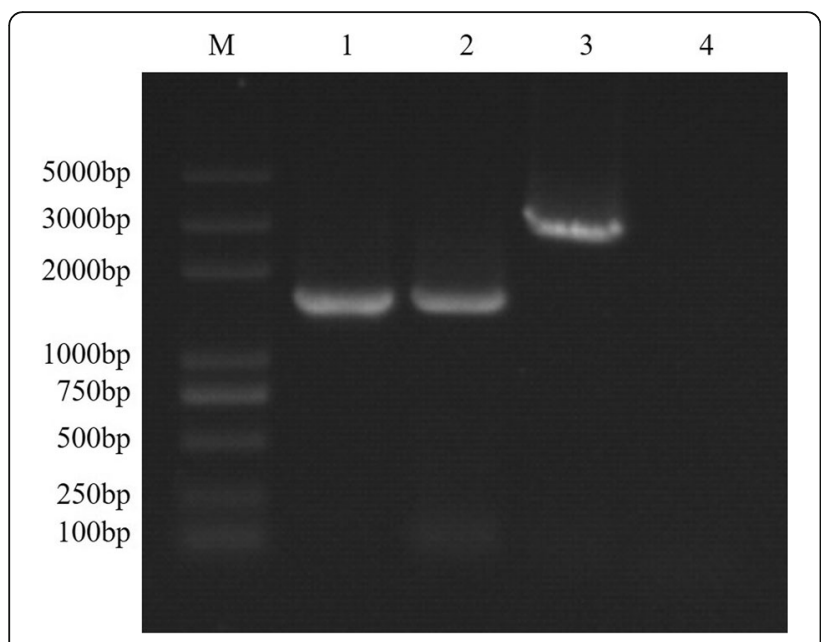

Fig. 2 Identification of the recombinant adenovirus by PCR. M: $2 \mathrm{~K}$ Plus DNA marker; 1: PCR product from rAd-IN; 2: PCR product from rAd-NJ; 3: PCR product from rAd-IN-NJ; 4: Negative control. rAd-IN, recombinant adenovirus-Indiana; rAd-NJ, recombinant adenovirusNew Jersey; rAd-IN-NJ, recombinant adenovirus-Indiana-New Jersey; $\mathrm{PCR}$, polymerase chain reaction

\section{Production and characterization of recombinant adenovirus}

The three rAds were inoculated into the AAV-293 cells and were serially propagated to 20 generations. The 5 th, 10th, 15th, and 20th generation rAds were collected to extract the viral DNA, and the VSV-IN-G gene (1536 bp), VSV-NJ-G gene (1554bp) and the VSV-IN-G-NJG gene (3100 bp) were then correctly identified using PCR and DNA sequencing, which matched the expected results (Fig. 3). No band was observed in the control group. The TCID 50 's of the 5th, 10th, 15th, and 20th rAd-IN generations were $10^{-8.56} / \mathrm{mL}, 10^{-}$ $8.16 / \mathrm{mL}, 10^{-8.96} / \mathrm{mL}$, and $10^{-8.34} / \mathrm{mL}$, respectively. The TCID $_{50}$ 's of the 5th, 10th, 15th, and 20th rAd-NJ generation were $10^{-7.76} / \mathrm{mL}, 10^{-8.16} / \mathrm{mL}, 10^{-7.67} / \mathrm{mL}$, and $10^{-8.2} / \mathrm{mL}$ respectively, and the corresponding values for $\mathrm{rAd}-\mathrm{IN}-\mathrm{NJ}$ were $10^{-6.96} / \mathrm{mL}, 10^{-7.16} / \mathrm{mL}$, $10^{-7.67} / \mathrm{mL}$, and $10^{-7.2} / \mathrm{mL}$ suggesting certain level of genetic stability of the rAds.

\section{Detection of protein expression by western blotting analyses and immunofluorescence assay}

The rAd-infected AAV-293 cells were assessed by western blotting to detect the expression of VSV-G. On the blots, the presence of $57 \mathrm{kDa}, 57 \mathrm{kDa}$, and $114 \mathrm{kDa}$ bands which corresponded to VSV-IN-G, VSV-NJ-G, and VSV-IN-GNJ-G, respectively, were observed (Figs. 4 and 5). Furthermore, rAd-IN and rAd-NJ were detected by the antibodies of the corresponding serotypes. Since the rAd-IN-NJ contained both the VSV-IN-G and VSV-NJ-G genes, both anti-VSV-IN-G protein mouse McAb and anti-VSV-NJ goat $\mathrm{PcAb}$ were used to detect the fusion protein.

Vero cells were infected with rAd-IN-NJ to detect the expression of VSV-G by immunofluorescence assay (IFA). IFA showed that specific green fluorescence was observed for rAd-IN-NJ, which was not detected in the negative control wild-type Ad (wtAd) (Fig. 6). These results demonstrated that the recombinant fusion $G$ protein could be expressed in-vitro following rAd infection in Vero cells, and that the protein could retain its antigenic reactivity.

\section{Virus neutralizing antibody responses}

The mice and goats immunized with rAds containing the VSV-G genes using a micro-neutralization assay suggested that these animals could produce neutralizing antibodies after immunization. The virus-neutralizing antibody (VNA) titers in all the experimental groups were low after the first immunization in mice and goats, but these titers significantly increased after the second immunization. As shown in Tables 1 and 2, VNA was

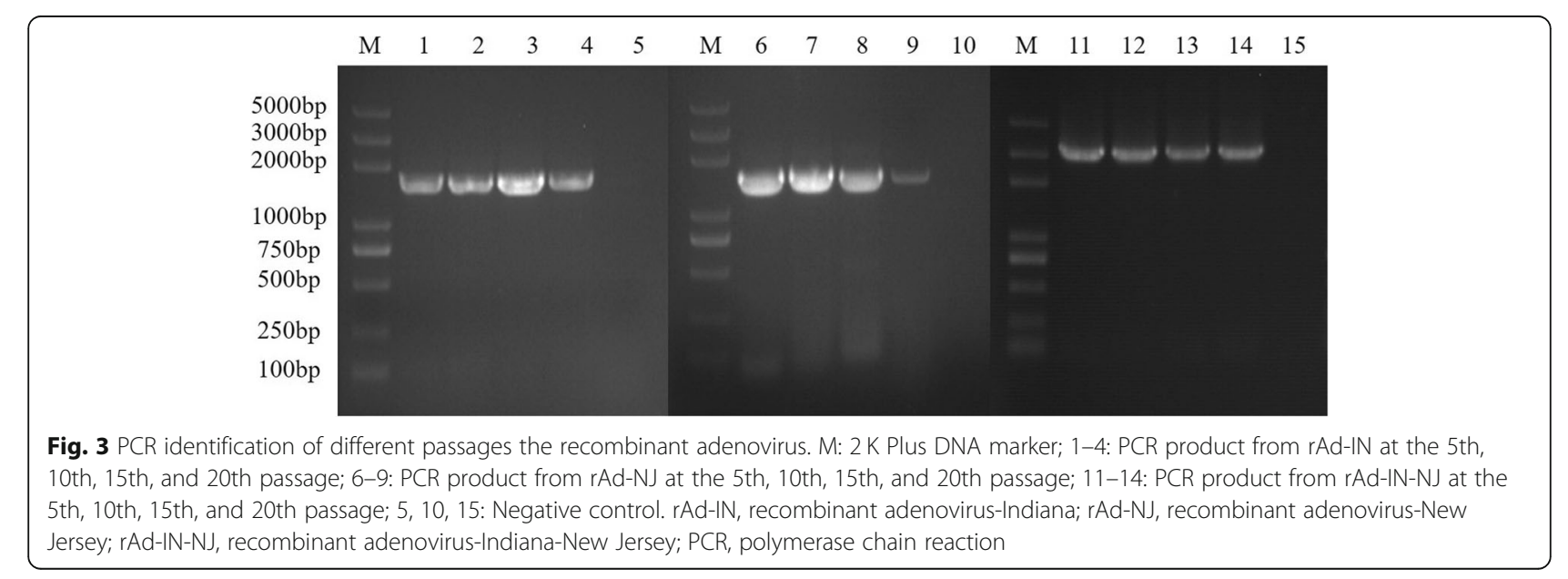




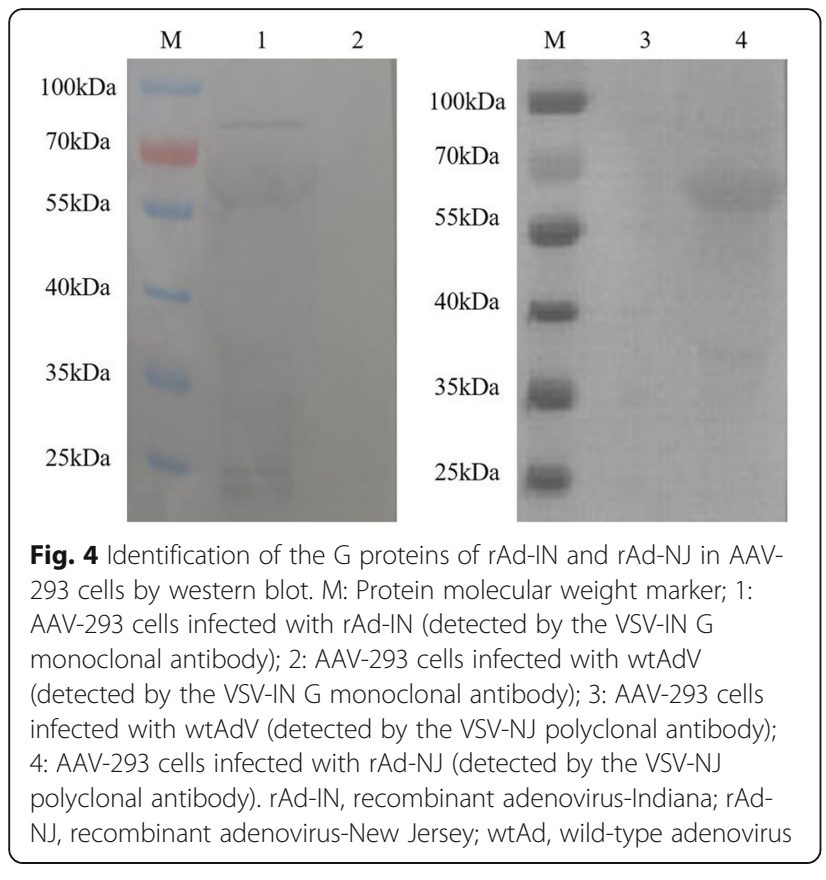

detected in mice and goats after immunization with rAd-IN or rAd-IN-NJ, and the VNA titers with VSV-IN ranged from 1:8 to 1:32 after the secondary immunization. Furthermore, as shown in Tables 3 and 4, the VNA titers with VSV-NJ were equal to or exceeded a ratio of 1:8 after the second immunization in the rAd$\mathrm{NJ}$ or rAd-IN-NJ vaccinated mice and goat groups. In the neutralization assay with VSV-IN, the VNA titer of the rAd-NJ group was lower than those of the rAd-IN or

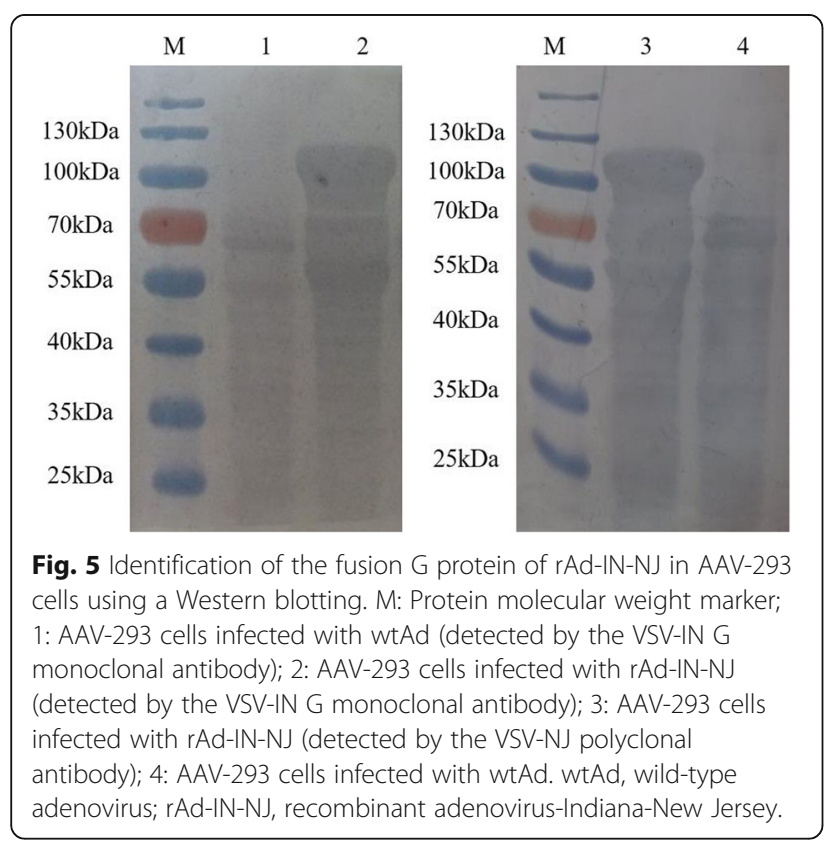

rAd-IN-NJ vaccinated mice and goat groups. Upon conducting the neutralization assay with VSV-NJ, the VNA titers of the rAd-NJ and rAd-IN-NJ groups were higher than that of the rAd-IN vaccinated mice and goat groups. As expected, no neutralization activity against VSV was detected in the pre-immune sera or in the sera of experimental animals injected with wtAd and phosphate-buffered saline (PBS).

\section{Lymphocyte proliferation response}

To investigate the cell-mediated immune responses induced by the three rAds, the lymphocyte proliferation responses of mice were analyzed 2 weeks after the third immunization. In case of goats, the lymphocyte proliferation responses were analyzed 6 weeks after the secondary immunization. VSV-IN and VSV-NJ are two different antigens that stimulated lymphocyte proliferation in different experimental groups. The data showed (Fig. 7 and 8) that mice and goats immunized with the rAds induced significantly stronger lymphocyte proliferation responses by VSV-IN and VSV-NJ compared with the PBS and wtAd control groups. When stimulated by VSV-IN, the lymphocyte proliferative responses in the rAd-IN and rAd-IN-NJ groups were stronger, with a stimulation index (SI) of approximately 2.5 . In addition, the SI of the rAd-IN-NJ group was relatively higher than those of the rAd-IN and rAd-NJ groups in mice and goats. There was a significant difference between the rAd groups and the PBS and wtAd control groups $(P<$ $0.05)$, but there was no significant difference among mice immunized with the different rAds $(P>0.05)$.

\section{Discussion}

Vesicular stomatitis is a viral disease that primarily affects horses, cattle, and swine. The virus is capable to affect a wide range of host including sheep and goats. Thus, effective vaccination is very important for the prevention and control of VS. Currently, controlling the spread of VS involves isolation of the affected animals, quarantining the affected premise and is mainly dependent on the immunization of susceptible animals. In addition to inactivated vaccines, live attenuated vaccines are widely used for immunization against VSV. However, due to the risk of virulence reversion in such vaccines, heat-stable, safe, and effective VS vaccines need to be developed.

The human type 5 replication-defective adenovirus expression vector is a common vector used in the research of vaccines and genetic therapy. The newly developed heat-stable technology enables adenovirus vector vaccines to be stored at room temperature up to $45^{\circ} \mathrm{C}$ for 6 months and maintain a steady infection hold. rAd vector vaccines can be inoculated using a variety of methods since they have a wider range of permissive host cells. As effective vaccine vectors both the replicative and non- 

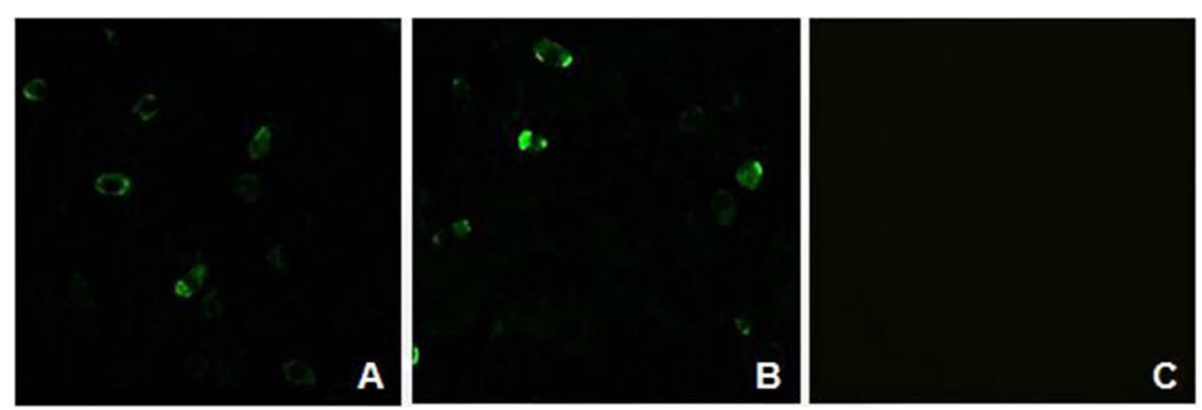

Fig. 6 Identification of the fuson G protein of rAd-IN-NJ in Vero cells using an immunofluorescence assay. A: Vero cells infected with rAd-IN-NJ (detected by the VSV-IN monoclonal antibody); B: Vero cells infected with rAd-IN-NJ (detected by the VSV-NJ polyclonal antibody); C: Vero cells infected with wtAd control (detected by the VSV-IN monoclonal or VSV-NJ polyclonal antibody). rAd, recombinant adenovirus; wtAd, wild-type adenovirus; rAd-IN-NJ, recombinant adenovirus-Indiana-New Jersey; VSV-IN, vesicular stomatitis virus-Indiana; VSV-NJ, vesicular stomatitis virus-New Jersey

replicative adenovirus are long been used to infect a wide varieties of mammalian cells to to expression higher level of recombinant proteins [20-25]. Considering these advantages, it is valuable to perform further research for the development of vaccine candidates using an adenovirus vector for the prevention and control of VS.

VSV glycoprotein plays major role in the mechanism of disease production in in many of the natural host including pigs [26]. Therefore, in this study we targeted VSV glycoproteingenes to clone and induce with an aim to induce VSV-G proteins for better immune response. It has been reported that the recombinant VSV-IN containing VSV-NJ-G-IN-G expressed both glycoproteins stably through multiple rounds of replication in pigs and induced neutralizing antibodies against both VSV serotypes [10, 26]. In our study, the genes for both VSV-G serotypes were accurately cloned by reverse transcription-PCR (RT-PCR), and the fusion VSV-IN-GNJ-G gene of $3100 \mathrm{bp}$ was successfully amplified by overlapping PCR using the GlyGlyGlyGlySer polypeptides.
In order to determine the best time to harvest the rAds from the cell culture, we performed numerous rAd optimization experiments, and found that 10-15 days was the appropriate time to harvest the rAds. In addition, PCR was conducted to amplify the target genes from the cell culture supernatants containing rAds to confirm the genetic stability of the VSV-G genes. The western blotting and IFA results suggested that the three target proteins could be expressed in AAV-293 cells and Vero cells, but that rAd could only induce a CPE in AAV-293 cells at 36-48 $\mathrm{h}$ after virus infection.

One of the major aim of the study was to evaluate the immunogenicity of the newly constructed rAds. Mice and goats inoculated with rAd-IN, rAd-NJ, or rAd-INNJ were subjected to virus neutralization test to detect neutralizing antibody levels in their sera at different time interval. The results of the lymphocyte proliferation test showed that the rAds could elicit lymphocyte proliferation in mice and goats, and was significantly higher compared to the negative control groups $(P<0.05)$.
Table 1 Detection of VSV neutralizing antibodies in mice induced by recombinant adenovirus with VSV-IN at different time points

\begin{tabular}{lllll}
\hline \multirow{2}{*}{ rroup } & \multicolumn{4}{l}{ Mean titers over time after first immunization } \\
\cline { 2 - 5 } & 0 weeks & 2 weeks & 4 weeks & 6 weeks \\
\hline rAd-IN & 0 & $<2(0-2)$ & $10.4(8-16)$ & $24(16-32)$ \\
rAd-NJ & 0 & $<2(0-2)$ & $6(4-8)$ & $10.4(8-16)$ \\
rAd-IN-NJ & 0 & $<2(0-2)$ & $24(16-32)$ & $28.8(16-32)$ \\
wtAd & 0 & 0 & 0 & 0 \\
PBS & 0 & 0 & 0 & 0
\end{tabular}

${ }^{a}$ Mean neutralizing antibody titers at that time point (range of antibody titers). VSV-IN vesicular stomatitis virus-Indiana; $r A d-I N$ recombinant adenovirusIndiana; rAd-NJ recombinant adenovirus-New Jersey; rAd-IN-NJ recombinant adenovirus-Indiana-New Jersey; wtAd wild-type adenovirus; PBS phosphate-buffered saline
Table 2 Detection of VSV neutralizing antibodies in goats induced by recombinant adenovirus with VSV-IN at different time points

\begin{tabular}{llllll}
\hline Group & \multicolumn{5}{l}{ Mean titers over time after first immunization } \\
\cline { 2 - 6 } & $\mathbf{0}$ weeks & $\mathbf{3}$ weeks & $\mathbf{6}$ weeks & $\mathbf{9}$ weeks & $\mathbf{1 2}$ weeks \\
\hline rAd-IN & 0 & $7(4-8)$ & $28(16-32)$ & $56(32-64)$ & $28(16-32)$ \\
rAd-NJ & 0 & $7(4-8)$ & $14(8-16)$ & $14(8-16)$ & $10(8-16)$ \\
rAd-IN-NJ & 0 & $7(4-8)$ & $14(8-16)$ & $24(16-32)$ & $20(16-32)$ \\
wtAd & 0 & 0 & 0 & 0 & 0 \\
PBS & 0 & 0 & 0 & 0 & 0 \\
\hline
\end{tabular}

${ }^{a}$ Mean neutralizing antibody titers at that time point (range of antibody titers). VSV-IN vesicular stomatitis virus-Indiana; $r A d-I N$ recombinant adenovirusIndiana; $r A d-N J$ recombinant adenovirus-New Jersey; $r A d-I N-N J$ recombinant adenovirus-Indiana-New Jersey; wtAd wild-type adenovirus; PBS phosphate-buffered saline 
Table 3 Detection of VSV neutralizing antibodies in mice induced by recombinant adenovirus with VSV-NJ at different time points

\begin{tabular}{lllll}
\hline Group & \multicolumn{4}{l}{ Mean titers over time after first immunization } \\
\cline { 2 - 5 } & $\mathbf{0}$ weeks & $\mathbf{2}$ weeks & $\mathbf{4}$ weeks & $\mathbf{6}$ weeks \\
\hline rAd-IN & 0 & $<2(0-2)$ & $6(4-8)$ & $8(8)$ \\
rAd-NJ & 0 & $<2(0-2)$ & $10.4(8-16)$ & $24(16-32)$ \\
rAd-IN-NJ & 0 & $<2(0-2)$ & $12(8-16)$ & $27.2(16-32)$ \\
wtAd & 0 & 0 & $6(4-8)$ & $8(8)$ \\
PBS & 0 & 0 & $10.4(8-16)$ & $24(16-32)$ \\
\hline
\end{tabular}

${ }^{a}$ Mean neutralizing antibody titers at that time point (range of antibody titers). VSV-NJ vesicular stomatitis virus-New Jersey; $r A d-I N$ recombinant adenovirusIndiana; $r A d-N J$ recombinant adenovirus-New Jersey; $r A d-I N-N J$ recombinant adenovirus-Indiana-New Jersey; wtAd wild-type adenovirus; $P B S$ phosphate-buffered saline

\section{Conclusions}

The newly constructed rAds efficiently expressed the foreign proteins (VSV-IN-G, VSV-NJ-G, and VSV-IN-GNJ-G). In immunized mice and goats these expressed proteins were able to induce certain degree of both a humoral and cellular immune responses. Mice and goats may be used as model animals to evaluate the VSV vaccine through challenge studies.

\section{Methods}

\section{Ethical permission}

All experiments were approved by the Ethics committee of Institute of Animal Sciences, Chinese Academy of Agricultural Sciences (permit number: 2015-014). All manipulations were carried out in accordance with the requirements of the Regulations of Experimental Animal Administration of China.

\section{Cells and viruses}

AAV-293 and Vero cells were cultured in Dulbecco's Modified Eagle's Medium (DMEM) containing 10\% fetal bovine serum (FBS), $100 \mathrm{IU} / \mathrm{mL}$ penicillin, and $100 \mathrm{IU} /$ $\mathrm{mL}$ streptomycin at $37^{\circ} \mathrm{C}$ in $5 \% \mathrm{CO}_{2}$. VSV-IN and VSV$\mathrm{NJ}$ stocks were propagated and titrated in Vero cells.

\section{Experiment animals}

6-8-week-old female BALB/c mice were purchased from the Chinese Experimental Animal Resources Research Institute for Food and Drug Control (Beijing, China). Outbred healthy Boer goats (6 months old) were purchased from local self-supporting farmers in Fuyang, China.

\section{Construction of plasmids and recovery of recombinant viruses}

The VSV-IN-G gene was amplified by reverse transcription-PCR (RT-PCR) from the purified viral (VSV-IN) RNA using the following two primers: 5'CGGAATTC $_{E c o R}{ }_{\text {I }}$ GCCACC $_{(\text {kozak }}$ sequence) ATGAAGTG CCTTTTGTA-3' and 5' -ATTTGCGGCCGC $_{\text {Not } \mathrm{I}}$ TTAC TTTCCAAGTCGGTTC-3'.

The VSV-NJ-G gene was amplified by RT-PCR from the purified viral (VSV-NJ) RNA using the following primers: 5 '-CGGAATTC ${ }_{E c o R}{ }_{\mathrm{I}} \mathrm{GCCACC}_{\text {(kozak }}$ sequenсе)ATGTTGTCTTATCTAATCTTTGCA-3' and 5' ATTTGCGGCCGC $_{N o t}$ ITAACGGAAATGAGCCAT TTCCACG-3'. The gene for the VSV-IN-G-NJ-G fusion protein was amplified by overlapping PCR of polypeptides Gly-Gly-Gly-Gly-Ser and the following two primers (containing the linkers' gene sequence): 5'-GGTGGA

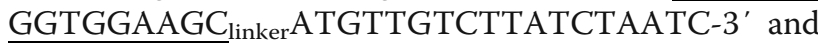
$5^{\prime}$-GCTTCCACCTCCACC linker $_{\text {CTTCCAAGTCGGT }}$ $\mathrm{TC}-3^{\prime}$.

The target genes (VSV-IN-G, VSV-NJ-G, VSV-IN-GNJ-G) and the adenovirus shuttle vector (pacAd-CMV $\mathrm{K}-\mathrm{NpA}$ ) were digested with restriction enzymes EcoR I and Not I. Then, the fragments were cloned into the shuttle vector and ligated with the T4 DNA ligase to construct the recombinant shuttle plasmids containing the target genes (pAd-VSV-IN-G, pAd-VSV-NJ-G, pAdVSV-IN-G-NJ-G). The recombinant shuttle plasmids and adenovirus backbone plasmids linearized with $\mathrm{PacI}$ restriction enzymes were co-transferred into an AAV293 cell monolayer in six-well tissue culture plates (Costar, Corning, NY, USA) using Lipofectamine-2000 reagent (Invitrogen, USA) as per manufacturer's

Table 4 Detection of VSV neutralizing antibodies in goats induced by recombinant adenovirus with VSV-NJ at different time points

\begin{tabular}{|c|c|c|c|c|c|}
\hline \multirow[t]{2}{*}{ Group } & \multicolumn{4}{|c|}{ Mean titers over time after first immunization ${ }^{a}$} & \multirow[b]{2}{*}{12 weeks } \\
\hline & 0 weeks & 3 weeks & 6 weeks & 9 weeks & \\
\hline rAd-IN & 0 & $5(4-8)$ & $10(8-16)$ & $10(8-16)$ & $12(8-16)$ \\
\hline rAd-NJ & 0 & $6(4-8)$ & $20(16-20)$ & $47(32-64)$ & $20(16-32)$ \\
\hline rAd-IN-NJ & 0 & $6(4-8)$ & $18(8-18)$ & $47(32-64)$ & $24(16-24)$ \\
\hline wtAd & 0 & 0 & 0 & 0 & 0 \\
\hline PBS & 0 & 0 & 0 & 0 & 0 \\
\hline
\end{tabular}

${ }^{a}$ Mean neutralizing antibody titers at that time point (range of antibody titers). VSV-NJ vesicular stomatitis virus-New Jersey; $r A d-I N$ recombinant adenovirusIndiana; $r A d-N J$ recombinant adenovirus-New Jersey; rAd-IN-NJ recombinant adenovirus-Indiana-New Jersey; wtAd wild-type adenovirus; PBS, phosphate-buffered saline 


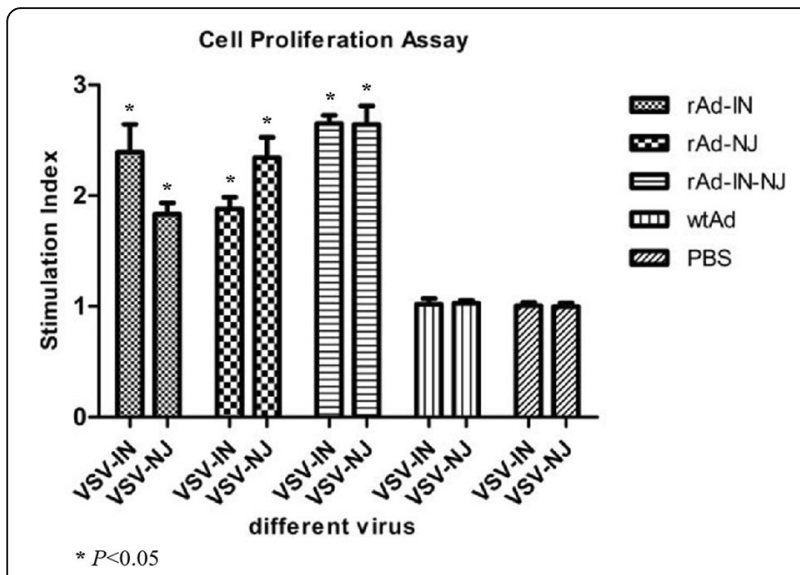

Fig. 7 Proliferation of splenocytes to virus stimulation in the immunized mice. rAd-IN, recombinant adenovirus-Indiana; rAd-NJ, recombinant adenovirus-New Jersey; rAd-IN-NJ, recombinant adenovirus-Indiana-New Jersey; wild-type adenovirus; PBS, phosphate-buffered saline; VSV-IN, vesicular stomatitis virus-Indiana; VSV-NJ,vesicular stomatitis virus-New Jersey

instruction. The three rAds constructed in this study were named rAd-IN, rAd-NJ, and rAd-IN-NJ.

The three rAds inoculated into the AAV-293 cells were serially propagated to 20 generations. The CPE was observed and recorded 3 days post-incubation, and $\mathrm{TCID}_{50}$ was calculated using the Reed-Muench method.

\section{Detection of expressing G protein by western blotting and IFA}

AAV-293 cells were infected with rAd-IN, rAd-NJ and rAd-IN-NJ. Mouse anti-VSV-IN-G protein McAb, goat anti-VSV-NJ-G protein PcAb were used to detect the

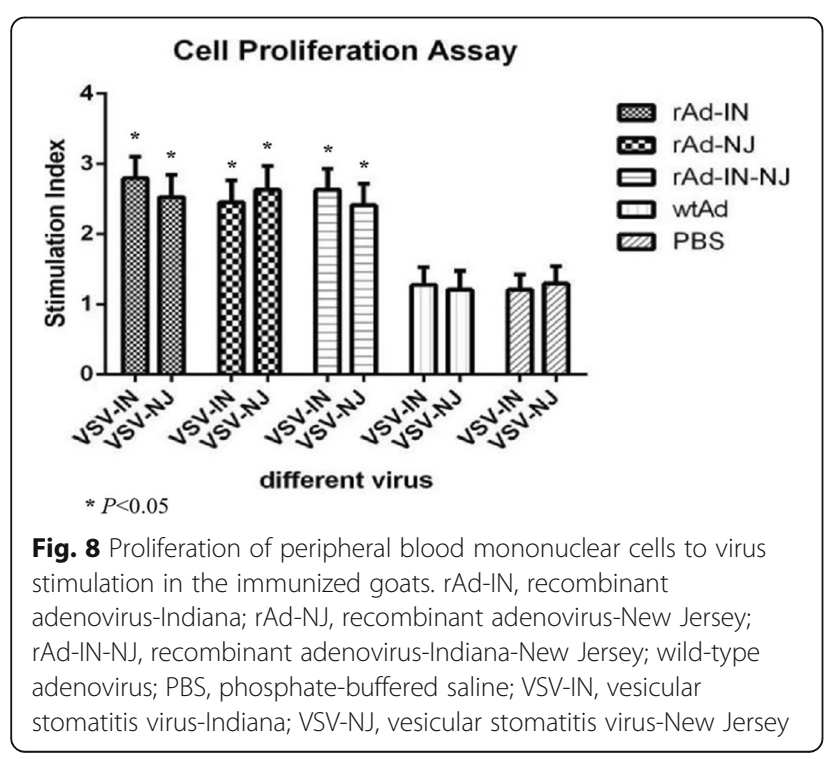

expression of the VSV-IN-G protein and VSV-NJ-G in rAds by western blotting as previously described [27].

For the IFA, Vero cells infected with rAd-IN-NJ were fixed with paraformaldehyde for $30 \mathrm{~min}$ at $4{ }^{\circ} \mathrm{C}$. After washing three times with PBST, the cells were incubated with anti-VSV-IN-G protein mouse McAb (1:2000) or anti-VSV-NJ goat PcAb (1:500). Following fluorescein isothiocyanate (FITC) labeled goat anti-mouse IgG or FITC- rabbit anti-goat IgG were applied and incubated for $30 \mathrm{~min}$ at $37^{\circ} \mathrm{C}$. The cells were then washed three times and visualized under a fluorescent microscope.

\section{Immunization of mice and goat and sample collection}

Mice: In order to evaluate the immune response to the rAds, the study selected 50 six-eight week-old female $\mathrm{BALB} / \mathrm{c}$ mice. Mice were randomly divided into five groups, with 10 mice per group. The three groups of mice were respectively inoculated subcutaneously three times at two-week intervals with $10^{8} \mathrm{TCID}_{50}$ rAd-IN, rAd-NJ, or rAd-IN-NJ. Two mice groups were respectively inoculated with the wild-type adenovirus and PBS, which were used as the negative control.

After 0, 2, 4, and 6 weeks of the first inoculation, blood was collected from the retrobulbar plexus of the mice. The serum was collected from the blood, incubated at $4{ }^{\circ} \mathrm{C}$, and centrifuged at $4{ }^{\circ} \mathrm{C}(3000 \mathrm{rpm}$ for $10 \mathrm{~min})$. Then the serum was stored at $-20^{\circ} \mathrm{C}$ for future use to detect specific antibody levels using a neutralization test. At the end of the experiments, the mice were euthanized using $\mathrm{CO}_{2}$ as previously described [28]. During the bleeding from retrobulbar plexus, the mice were anesthetized using phenobarbital.

Goats: 20 outbred healthy Boer goats (6 months old) were divided randomly into five groups, with four goats per group, and housed in separate rooms. All goats were negative for VSV infection as assessed by neutralizing antibodies (titers $<1: 2$ ). Groups 1,2 , and 3 were subcutaneously injected twice at three-week intervals with $10^{8}$ $\mathrm{TCID}_{50} / \mathrm{mL}$ rAd-IN, rAd-NJ, or rAd-IN-NJ. Groups 4 and 5 were inoculated subcutaneously with $10^{8} \mathrm{TCID}_{50} /$ $\mathrm{mL}$ wtAd or $1 \mathrm{~mL}$ PBS as negative controls. On $0,3,6$, 9, and 12 weeks post-inoculation, blood was collected from the vein of each goat. Sera were collecting from the blood, incubated at $4{ }^{\circ} \mathrm{C}$, and centrifuged at $4{ }^{\circ} \mathrm{C}(3000$ $\mathrm{rpm}$ for $10 \mathrm{~min})$. Then, the sera were stored at $-20^{\circ} \mathrm{C}$ for future use to detect specific antibody levels using a neutralization test. At the end of the experiment, the goats were continued to feed.

\section{Determination of neutralizing antibody titers}

Sera were collected and incubated at $56{ }^{\circ} \mathrm{C}$ for $30 \mathrm{~min}$ to inactivate complements. The sera were diluted five-fold with DMEM, and then serially diluted two-fold in DMEM. Serial dilutions of the serum were incubated 
with $200 \mathrm{TCID}_{50}$ of wild-type viruses (VSV-IN or VSV$\mathrm{NJ}$ ) for $1 \mathrm{~h}$ at $37^{\circ} \mathrm{C}$. After incubation, samples were added to Vero cells in quadruplicate assays in 96-well plates, and incubated at $37^{\circ} \mathrm{C}$ for 3 days. The CPE was observed and recorded 3 days after incubation. The VNA titer was defined as the highest serum dilution that inhibited CPE by at least $50 \%$. A titer equivalent to 10 or higher was considered positive in this study.

\section{Lymphocyte proliferation assay}

The lymphocyte proliferation assay for mice was conducted 2 weeks after the third immunization. Spleens were aseptically removed from three mice from each group and splenocyte suspensions were prepared. The splenocytes were extracted and purified using a Splenocyte Extraction kit (TBD Science, Tianjin, China) and seeded in 96-well flat-bottom plates at a density of $2 \times$ $10^{6}$ cells per well in RPMI 1640 medium (Invitrogen, Grand Island, NY, USA) containing 10\% FBS. Then, $100 \mu \mathrm{L}$ of medium containing VSV-IN or VSV-NJ was added to each well of splenocytes. Concanavalin A (ConA) (Sigma Aldrich, St. Louis, MO, USA) was used as a positive control, and the medium was used as a negative control. The plates were incubated at $37^{\circ} \mathrm{C}$ in $5 \% \mathrm{CO}_{2}$ for 3 days. After 3 days, the proliferative response was determined using the Cell Titer 96 Aqueous One Solution Cell Proliferation kit (Promega, Madison, WI, USA), following the manufacturer's instructions.

The lymphocyte proliferation assay for goats was conducted at week 9 after the first immunization. Blood was collected from the jugular vein of goats and was heparinized. Then, peripheral blood mononuclear cells (PBMC) were separated by Filoll-Hypque density gradient centrifugation (TBD Sciences, Tianjin, China), as described previously [27].

\section{Statistical analysis}

The data generated in this study were analyzed using a one-way ANOVA method of the GraphPad Prism version 5.00 (GraphPad Software, San Diego, CA, USA). A $p$ values less than 0.05 were considered statistically significant.

\section{Supplementary Information}

The online version contains supplementary material available at https://doi. org/10.1186/s12917-020-02740-6

\section{Additional file 1.}

\section{Abbreviations}

CMV: Cytomegalovirus; CPE: Cytopathic effect; DIVA: Differentiating infected from vaccinated animals; DMEM: Dulbecco's Modified Eagle's medium; FITC: Fluorescein isothiocyanate; FBS: Fetal bovine serum;

IFA: immunofluorescence assay; Kb: Kilobase; MOI: Multiplicity of infection; OIE: Office International des Epizooties, World Organization for Animal Health; PBMC: Peripheral blood mononuclear cell; PBS: Phosphate-buffered saline; rAd: Recombinant adenoviruses; RT-PCR: Reverse transcriptionpolymerase chain reaction; VNA: Virus-neutralizing antibody; VS: Vesicular stomatitis; VSV: Vesicular stomatitis virus; VSV-IN: Vesicular stomatitis virusIndiana; VSV-IN-G: Vesicular stomatitis virus Indiana serotype glycoprotein; VSV-NJ: Vesicular stomatitis virus- New Jersey; VSV-NJ-G: Vesicular stomatitis virus New Jersey serotype glycoprotein

\section{Acknowledgments}

We thank Dr. John Crowther for his critical revision on this manuscript, Drs Dongwan Yoo and Md. Tanvir Rahman for their assistance in writing the manuscript.

\section{Authors' contributions}

GL and SC designed the study and provided instructions. XX and ZY contributed equally to writing the manuscript. $X X, Z Y, H J, L L, J L, X L$, and $Y W$ performed the experiments. All authors read and approved the final manuscript.

\section{Funding}

This study is financially supported by the National Key Research and Development Plan of China (No. 2016YFD0501102), the National Natural Science Foundation of China (No. 31472203) and the National Science and Technology Support Program of China (No. 2013BAD12B05). The funders had no role in the study design, data analysis, and decision to publish, or preparation of the manuscript.

\section{Availability of data and materials}

The datasets used and analyzed during the current study are available from the corresponding author on reasonable request.

\section{Ethics approval and consent to participate}

All of the animal protocols were performed in accordance with the 'Guidelines for Experimental Animals' of the Ministry of Science and Technology (Beijing, China), and the study was approved by the Research Ethics Committee of the Chinese Academy of Agricultural Sciences (permit number: 2015-014). No specific permits were required for these locations and activities. The owners gave their written consent for sample collection, and the locations where samples were collected are not privately owned or protected in any way.

\section{Consent for publication}

Not applicable.

\section{Competing interests}

The authors declare that they have no competing interests.

\section{Author details}

${ }^{1}$ Beijing Scientific Observation and Experiment Station for Veterinary Drugs and Diagnostic Technology, Ministry of Agriculture and Rural Affairs, China /Institute of Animal Sciences, Chinese Academy of Agricultural Sciences, Beijing 100193, China. ${ }^{2}$ Anhui Province Key Laboratory of Veterinary Pathobiology and Disease Control, College of Animal Science and Technology, Anhui Agricultural University, Hefei 230036, China. ${ }^{3}$ Tibet Vocational Technical College, Lhasa 850000, China.

Received: 12 December 2019 Accepted: 29 December 2020 Published online: 18 January 2021

References

1. Heo EJ, Lee HS, Jeoung HY, Ko HR, Kweon CH, Ko YJ. Development of a blocking ELISA using a recombinant glycoprotein for the detection of antibodies to vesicular stomatitis New Jersey virus. J Virol Methods. 2010; 164(1-2):96-100.

2. Schmitt B. Vesicular stomatitis. Vet Clin North Am Food Anim Pract. 2002; 18(3):453-9.

3. Timoney P. Vesicular stomatitis. Vet Rec. 2016;179(5):119-20.

4. Mead DG, Lovett KR, Murphy MD, Pauszek SJ, Smoliga G, Gray EW, Noblet R, Overmyer J, Rodriguez LL. Experimental transmission of vesicular stomatitis New Jersey virus from Simulium vittatum to cattle: clinical outcome is influenced by site of insect feeding. J Med Entomol. 2009;46(4):866-72. 
5. Fathi A, Dahlke C, Addo MM. Recombinant vesicular stomatitis virus vector vaccines for WHO blueprint priority pathogens. Hum Vaccin Immunother. 2019;15(10):2269-85.

6. Fernandez J, Aguero M, Romero L, Sanchez C, Belak S, Arias M, SanchezVizcaino JM. Rapid and differential diagnosis of foot-and-mouth disease, swine vesicular disease, and vesicular stomatitis by a new multiplex RT-PCR assay. J Virol Methods. 2008;147(2):301-11.

7. Ferris NP, Clavijo A, Yang M, Velazquez-Salinas L, Nordengrahn A, Hutchings $\mathrm{GH}$, Kristersson T, Merza M. Development and laboratory evaluation of two lateral flow devices for the detection of vesicular stomatitis virus in clinical samples. J Virol Methods. 2012;180(1-2):96-100.

8. Martinez I, Wertz GW. Biological differences between vesicular stomatitis virus Indiana and New Jersey serotype glycoproteins: identification of amino acid residues modulating pH-dependent infectivity. J Virol. 2005;79(6):3578-85.

9. McCluskey BJ, Pelzel-McCluskey AM, Creekmore L, Schiltz J. Vesicular stomatitis outbreak in the southwestern United States, 2012. J Vet Diagn Invest. 2013;25(5):608-13.

10. Martinez I, Barrera JC, Rodriguez LL, Wertz GW. Recombinant vesicular stomatitis (Indiana) virus expressing New Jersey and Indiana glycoproteins induces neutralizing antibodies to each serotype in swine, a natural host. Vaccine. 2004:22(29-30):4035-43.

11. House JA, House C, Dubourget P, Lombard M. Protective immunity in cattle vaccinated with a commercial scale, inactivated, bivalent vesicular stomatitis vaccine. Vaccine. 2003;21(17-18):1932-7.

12. Perez AM, Pauszek SJ, Jimenez D, Kelley WN, Whedbee Z, Rodriguez LL. Spatial and phylogenetic analysis of vesicular stomatitis virus overwintering in the United States. Prev Vet Med. 2010;93(4):258-64.

13. Velazquez-Salinas L, Pauszek SJ, Zarate S, Basurto-Alcantara FJ, VerdugoRodriguez A, Perez AM, Rodriguez LL. Phylogeographic characteristics of vesicular stomatitis New Jersey viruses circulating in Mexico from 2005 to 2011 and their relationship to epidemics in the United States. Virology. 2014:449:17-24.

14. Cantlon JD, Gordy PW, Bowen RA. Immune responses in mice, cattle and horses to a DNA vaccine for vesicular stomatitis. Vaccine. 2000;18(22):2368-74.

15. Mizuguchi H, Hayakawa T. Characteristics of adenovirus-mediated tetracycline-controllable expression system. Biochim Biophys Acta. 2001; 1568(1):21-9.

16. Deal C, Pekosz A, Ketner G. Prospects for oral replicating adenovirusvectored vaccines. Vaccine. 2013;31(32):3236-43.

17. Small JC, Ertl HC. Viruses - from pathogens to vaccine carriers. Curr Opin Virol. 2011;1(4):241-5.

18. Mathieu ME, Grigera PR, Helenius A, Wagner RR. Folding, unfolding, and refolding of the vesicular stomatitis virus glycoprotein. Biochemistry. 1996; 35(13):4084-93.

19. Sun C, Zhao K, Chen K, He W, Su G, Sun X, Wang L, Pan W, Zhang W, Gao F, Song D. Development of a convenient immunochromatographic strip for the diagnosis of vesicular stomatitis virus serotype Indiana infections. J Virol Methods. 2013;188(1-2):57-63.

20. Shiver JW, Fu TM, Chen L, Casimiro DR, Davies ME, Evans RK, Zhang ZQ, Simon AJ, Trigona WL, Dubey SA, Huang L, Harris VA, Long RS, Liang X, Handt L, Schleif WA, Zhu L, Freed DC, Persaud NV, Guan L, Punt KS, Tang A, Chen M, Wilson KA, Collins KB, Heidecker GJ, Fernandez VS, Perry HC, Joyce JG, Grimm KM, Cook JC, Keller PM, Kresock DS, Mach H, Troutman RD, Isopi LA, Williams DM, Xu Z, Bohannon KE, Volkin DB, Montefiori DC, Miura A, Krivulka GR, Lifton MA, Kuroda MJ, Schmitz JE, Letvin NL, Caulfield MJ, Bett AJ, Youil R, Kaslow DC, Emini EA. Replication-incompetent adenoviral vaccine vector elicits effective anti-immunodeficiency-virus immunity. Nature. 2002:415(6869):331-5.

21. Casimiro DR, Chen L, Fu TM, Evans RK, Caulfield MJ, Davies ME, Tang A, Chen M, Huang L, Harris V, Freed DC, Wilson KA, Dubey S, Zhu DM, Nawrocki D, Mach H, Troutman R, Isopi L, Williams D, Hurni W, Xu Z, Smith JG, Wang S, Liu X, Guan L, Long R, Trigona W, Heidecker GJ, Perry HC, Persaud N, Toner TJ, Su Q, Liang X, Youil R, Chastain M, Bett AJ, Volkin DB, Emini EA, Shiver JW. Comparative immunogenicity in rhesus monkeys of DNA plasmid, recombinant vaccinia virus, and replication-defective adenovirus vectors expressing a human immunodeficiency virus type $1 \mathrm{gag}$ gene. J Virol. 2003;77(11):6305-13.

22. Hernandez J, Rascon-Castelo E, Bray J, Lokhandwala S, Mwangi W. Immunogenicity of a recombinant adenovirus expressing porcine reproductive and respiratory syndrome virus polyepitopes. Vet Microbiol. 2017;212:7-15.
23. Wang AP, Liu L, Gu LL, Guo CM, Wu S, Feng Q, Xia WL, Wu Z, Zhu SY. Protection against duck hepatitis a virus type 1 conferred by a recombinant avian adeno-associated virus. Poult Sci. 2019;98(1):112-8.

24. Wang $X$, Fang $Z$, Xiong J, Yang $K$, Chi $Y$, Tang $X$, Ma L, Zhang R, Deng F, Lan K, Zhou D. A chimpanzee adenoviral vector-based rabies vaccine protects beagle dogs from lethal rabies virus challenge. Virology. 2019; 536:32-8

25. Wu Y, Yang D, Xu B, Liang W, Sui J, Chen Y, Yang $H$, Chen $H$, Wei P, Qiao C. Immune efficacy of an adenoviral vector-based swine influenza vaccine against antigenically distinct H1N1 strains in mice. Antiviral Res. 2017;147: 29-36.

26. Martinez I, Rodriguez LL, Jimenez C, Pauszek SJ, Wertz GW. Vesicular stomatitis virus glycoprotein is a determinant of pathogenesis in swine, a natural host. J Virol. 2003;77(14):8039-47.

27. Wang Y, Liu G, Chen Z, Li C, Shi L, Li W, Huang H, Tao C, Cheng C, Xu B, Li $\mathrm{G}$. Recombinant adenovirus expressing $\mathrm{F}$ and $\mathrm{H}$ fusion proteins of peste des petits ruminants virus induces both humoral and cell-mediated immune responses in goats. Vet Immunol Immunopathol. 2013;154:1-2):1-7.

28. Boivin GP, Bottomley MA, Grobe N. Responses of Male C57BL/6N Mice to Observing the Euthanasia of Other Mice. J Am Assoc Lab Anim Sci. 2016; 55(4):406-11.

\section{Publisher's Note}

Springer Nature remains neutral with regard to jurisdictional claims in published maps and institutional affiliations.
Ready to submit your research? Choose BMC and benefit from:

- fast, convenient online submission

- thorough peer review by experienced researchers in your field

- rapid publication on acceptance

- support for research data, including large and complex data types

- gold Open Access which fosters wider collaboration and increased citations

- maximum visibility for your research: over $100 \mathrm{M}$ website views per year

At BMC, research is always in progress.

Learn more biomedcentral.com/submissions 